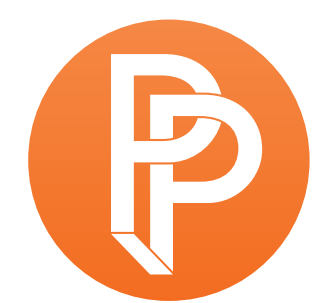

PERFORMANCE

PHILOSOPHY

\title{
TRAGEDY, IMMANENCE, AND THE PERSISTENCE OF SEMBLANCE
}

\author{
KAROLINE GRITZNER ABERYSTWYTH UNIVERSITY
}

The form of tragedy has been central to philosophical projects since classical antiquity, and it gained special critical import as a result of the so-called 'tragic turning within philosophy' during the Romantic period of German Idealism (see Beistegui 2000). The aim of this short paper is to address the notion of aesthetic appearance (semblance, Schein) within aesthetic theory (Theodor W. Adorno) and in contemporary tragic theatre (Howard Barker) and to show that the problem of semblance re-appears as a productive critical category in the current discourse of performance philosophy.

Howard Barker's tragic drama (which he calls a 'theatre of catastrophe', see Arguments for a Theatre) unfolds in a context of post-dramatic and post-metaphysical theatre, and, if one agrees with George Steiner's analysis, it lacks the signifiers of 'authentic' tragedy because it develops in a cultural context that is devoid of a theological dimension (Steiner 1961, 2008). In Barker's theatre there are no super-human agencies determining the fate of dramatic characters; there is no sense of hope or redemption to be discovered in the face of the event of death; there is no ethical value system adhered to, and no moral statements (in the form of messages) made about the world. Following Nancy, one could argue that it is a theatre that comes 'after tragedy' because it "has no recourse, nor have we, to a higher (or more profound) truth, to which the "tragic" itself would open onto as to a possibility, in spite of everything, of making sense, even if it means making sense of the relinquishing of sense' (Nancy 2014, 284). Yet, even for Nancy, the concept of tragedy persists in postmodern times, because 'tragedy itself, already comes after' (ibid.). It comes after the catastrophe, after sacrifice, after the death of God and the crisis of subjectivity. 
The concept of tragedy implies a dialectical structure of feeling, which Steiner calls 'alienation' or 'estrangement from life' (the human experience of loss and of being a stranger to others and to oneself). In classical Greek tragedy, for example, the particular actions of a transgressive individual (the criminal acts of Medea, for instance, or the unconscious actions of Oedipus) are radically alienating gestures which are juxtaposed with the force of universal law, ethics and (absolute) power. By emphasising heightened emotional content, danger, radical action, violence and suffering, tragedy draws our attention to the singularity, finitude and precariousness of human experience. Tragic human experience manifests itself in the form of a limit experience.

But tragedy is also a structure of thought, a constructed conceptual system of relations between singularities; a mode of thinking which plays out its own logic of separation and negation (the tragic hero separates him/herself from the world; s/he negates existence and puts meaning on trial). In Barker's theatre in particular, the alienation of the central character is experienced as a profoundly individualising process, as a singularity that cannot adequately be thought. Tragedy thinks this eventuality of the particular, it thinks it to excess; and in thinking (tragically), thought reaches beyond the limits of its own conceptual boundaries and discovers the possibility of difference. In classic as well as postmodern tragic theatre, thought undoes itself in its violent encounter with immanence in a movement which, as Adorno proposed, draws attention to the 'nonidentical' kernel of the concept. In other words, the thoughts emerging from contingent theatrical gestures and actions resist their own logic of domination and transparency; they can be called immanent not least because they are (performance) 'thoughts that do not understand themselves' (Adorno 1974, 192).

In Barker's play I Saw Myself (written in 2007) the widowed female protagonist Sleev and her servants are in the process of weaving a gigantic tapestry which is to represent a record of the country's heroic political past and a celebration of the current war effort. Sleev, however, resists the ideological pressure of depicting glorified universal war-time experiences and attempts to insert her own personal and sexually transgressive adventures into the tapestry. She meets resistance, fear and hostility from others yet persists in revealing her subversive erotic past. The play contains the surrealistic image of a naked man inside a mirrored wardrobe; Sleev's recurring speculations about Adam and Eve's relationship before and after their expulsion from paradise; the women's painstaking labour of weaving 'the truth', which gradually damages their eyesight; the imminent catastrophe of an approaching war. The non-linear structural combination of these evocative gestures and thought images emphasises the irreconcilable tensions between the personal and the political as evoked in the theme of (subjective) reflection and (artistic) representation. The looming catastrophic collapse of the characters' physical world (the kind of closure that is threatened by war) is foreshadowed and resisted throughout the play by Sleev's intra- and inter-personal conflicts (her own 'war'). She finds an imaginative extension of her subjective world in and through the reflections provided by the mirror and her sexual partners. The reflexive gaze of the self in the mirror and in the 'other' provides a kind of reflective opening by means of which the circumstances of the present are defiantly challenged, without however offering a sense of moral resolution or hope for redemption. In Barker's work, passion and the 'de-civilising experience' and 'series of permissions to transgress' (Barker 1997, 110) which it 
invites, becomes a theatrical core principle that opposes the achievements and morality of the transparent, humanist world of Reason.

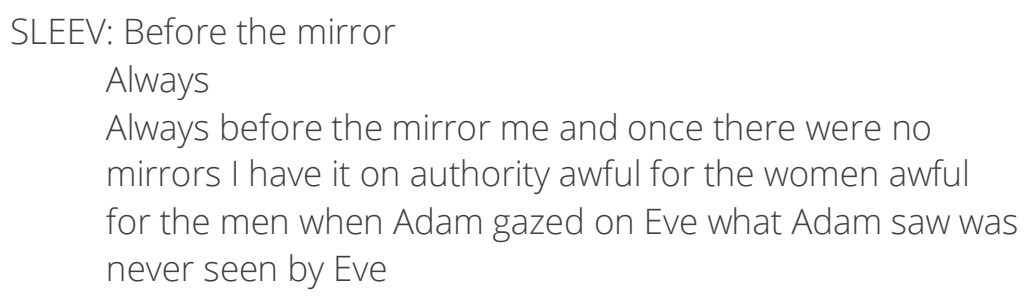

(Barker 2008, 13)

In an essay on Bizet's opera Carmen Adorno notes: 'For in the aesthetic refraction of passion subjectivity becomes conscious of itself as nature, and abandons the illusion that it is autonomous mind [Geist]' (Adorno 1998, 63). The subject who desires (in many ways the archetypal tragic figure) 'sees herself' in those moments of rupture and un-knowing which recall the force of uncontrollable nature. 'SLEEV: With desire came the mirror but the mirror only served to deepen the anxiety desire inevitably creates (She looks at herself.)' (Barker 2008, 14). In other words, the aesthetic presentation and appearance of subjectivity as divided, fractured, and in the process of self-conscious dissolution suggests a different way of understanding and thinking. Self-becoming (or self-recognition) in the process of self-dissolution (a Romantic idea which, incidentally, also shaped Friedrich Hölderlin's theory and practice) does not abandon thought to non-conceptual effusion, nor does it deliver speech to silence. Barker's theatre of catastrophe is a very powerful example of the relentless continuity or ordeal of philosophical thinking in the face of inexplicable, because uncontainable, human emotions. But, importantly, thought's wrestling with the boundless is translated into the actuality of dramatic stage action and therefore becomes material and immanent. 'The ordeal', as Nancy states in his discussion of the self in Hegel's philosophy, 'is that of immanence' (Nancy 2002, 55).

The dramatic form of tragedy, primarily due to its theatrical, emphatic, heightened and exaggerated form of address (in the form of dramatic speech) performs a negative, resistant mode of non-discursive thought which offers us a distinctively immanent and contingent perspective on what thinking is or can be. In his discussion of parataxis in the presentation of Hölderlin's poetry (and I argue that Barker's dramatic language is also paratactical), Adorno draws attention to the effect of conceptual spacing as a result of the distinctively constellatory lyric technique. The poet disregards syntax, punctuation and the logical ordering of thoughts and thus creates a ground or plane of poetic immanence (to borrow and amend Deleuze's key concept) on which thought emerges as thought in direct contact with the object or 'thing'. Nancy on Hegel again (and this, in my opinion, might function as a model for performance philosophy): '[t]hought is penetration into the thing, a breaking or sinking into the thing' (Nancy 2002, 19). This penetration of the thing by thought (Hegel uses the term 'spirit') does not, however, invite thought to stop or relinquish itself. On the contrary, contact with materiality and the concrete makes thought 'restless', self-reflexive and thus able to actualise itself as thought made manifest.

The problem of manifestation, or to use the related concepts of appearance and semblance, in 
aesthetic terms has been a concern for philosophers of art since Kant. German Idealism's contribution to the discourse around aesthetic appearance rests on the primary notion that the semblance character of the work of art is its ability to reach beyond the limitations of art's material object-ness to suggest the possibility of an ontological difference that is captured by the notion of a 'more', as Adorno has pointed out (see Adorno 1997). Adorno's treatment of semblance is deeply informed by his reception of the idealist discourse of art and philosophy which established a connection between aesthetic appearance and spirit (Geist). In the Hegelian tradition the spirit of art is the semblance of something immaterial (of an Idea, the Absolute), but it is unable to exist independently from the sensuous, material elements of the artwork, as I have discussed above in the context of thought's relation to the thing. However, the artwork's Schein cannot be identical with the material itself and it cannot be reduced to it, because such an identification would extinguish the difference or otherness of the artwork compared to other objects of empirical reality. Art as semblance is defined by this crucial element of difference from the real or, to use Adorno's language, by its negativity from that which 'merely exists'. In Aesthetic Theory he writes: 'Artistic spirit raises itself above what merely exists' (Adorno 1997, 48). This might sound like the opposite of Hegel's view (via Nancy) that thought must penetrate into the thing (that which exists) in order to realise itself as (restless) thought. However, both statements are in dialectical relation: by sinking into the materiality of being, thought (spirit) - in order to be perceived as such - also, at the same time, raises itself above that into which it is sinking. The sinking into the material becomes manifest in thought's reaching beyond the known and contingent towards a possibility and futurity that is not yet defined or circumscribed. The 'reaching beyond', which is triggered by a 'sinking into', alone does justice to the infinite singularity of that which is given to us in the (theatrically) distinct experience of presence.

Fredric Jameson's definition of traditional aesthetic meaning as the 'subsumption of a particular under a general' (Jameson 1990,169) refers to the historical trajectory of the concept of aesthetic appearance which prepared for the nominalist critique of this development. Jameson's discussion of Adorno's focus on the 'crisis and the agony of aesthetic appearance' (168) draws out the conflict between the nominalist desire for immediacy and the domination of the commodity form which becomes the new 'universal' and absolute, representing the inescapable reality of commodification in modern society. From this perspective the crisis of Schein as initiated by nominalism signifies not only an end - namely the disintegration of the aura and stable 'meaning' of the hermetic work of art - but paradoxically also a beginning. The apparent collapse of aesthetic meaning and semblance in modernism can be considered as initiating a renewed and heightened objectivation of aesthetic processes, which terminate in the fetishised products of the culture industry. Fetishisation seems to be the key force in this process. The nominalist focus on the particular - the immediate and, in Adornian terms, 'nonidentical' element - contains within itself a dynamic, the radicalism and futility of which are expressed in its fixation on the contingent and the heterogeneous, which for Adorno points towards the deaestheticisation (Entkunstung) of art itself. 'Artworks from which the apparition has been driven out without a trace are nothing more than husks, worse than what merely exists, because they are not even useful' (Adorno $1997,107)$. Hence, in late-capitalist contexts of reification the persistence of aesthetic semblance may be conceived as a protest against the mere existence of things; a response to the 
bureaucratic ordering of life.

While modernist art can be defined as an attempt to overturn the false semblance or illusion offered by traditional art - a reaction which led to formal fragmentation in the major modernist movements, such as expressionism, surrealism, dada, the developments in atonal music, and so forth - Adorno nevertheless defends art's quality of semblance (Scheincharacter). To him, 'central to aesthetics therefore is the redemption of semblance' (Adorno 1997, 107) because aesthetic semblance is here understood to rescue what the subjective spirit subjugates and dominates, namely the nonidentical and the immediate. The mere distance of art from empirical reality and heterogeneous nature - and without this distance or difference, however minimal, there would be no art - gives art the character of semblance. This is why nominalist critiques of Schein (as carried out by modernist avant-garde movements such as Surrealism, Dadaism, and Futurism) are critiques of art as such.

Aesthetic nominalism draws attention to the artwork's own structural impulse as opposed to an aesthetic organisation from a viewpoint 'above' or 'outside'. Adorno's stipulation that 'the artwork must be organised from below' following its own 'immanent movement' (Adorno 1997, 108) also pertains to his understanding of the relationship between art and philosophical thought, for thought should also become aware of its immanent movement in relation to the art object or event. The reaction of modernist art against aesthetic appearance/illusion (Schein) signifies an 'emancipation from the concept of harmony' (Adorno 1997, 100) which is the central concept of traditional, hermetic art. In Barker's post-metaphysical tragedies, the concept of harmony is equally displaced in favour of the dramaturgical principles of contradiction, interruption and irresolution.

Adorno's and Barker's critical engagements with the concept of aesthetic harmony reflect their views that individual experience in late-capitalist culture has become dangerously diminished this constitutes tragic experience today. Barker proposes that an encounter with tragic theatre reveals that 'the world is inadequate' (Barker 2005, 33) and 'wanting' (40), 'negative' in Adornian language. But the pain and anxiety (as a 'condition of tragedy') thus experienced, simultaneously create a longing in the individual for the unknown, a desire which rescues the authenticity of the self from its repressive and fateful entanglement in the 'irrationality of the system' (Adorno 1974, 23). If Barker's theatre can be termed 'irrational' - and thus an antagonism to the 'rational' liberalhumanist society, as Charles Lamb (2005) has suggested - its irrationality has to be understood dialectically; that is, as an aesthetic refraction of the irrationality of reality, similar to the ways in which the darkness of Beckett's plays is constructed as a mimesis of the darkness of the postAuschwitz world.

Barker's definition of tragedy, his 'art of theatre', combines art's propensity for transcendence and semblance (its drawing near the non-existent, its fascination with the other, its suggestion of a 'more') with a simultaneous discovery or instinctual and intuitive knowledge that the world is meaningless. His work is therefore a contemporary example of Adorno's call for a changed, postmetaphysical form of tragedy that neither lays an affirmative claim on the construction of 
positive meaning through art (by suggesting the possibility of reconciliation or redemption), nor does it repudiate the possibility of the impossible. In addition, this changed form of tragedy no longer stages the struggle of the particular with the universal (the classic example of tragedy where an individual's particular interests are only perceived as such if placed in opposition to a general, universal interest). Tragedy reaches beyond what is merely the case; it welcomes the extraordinary, the extreme, the catastrophic; it brings chaos to order. As the brief example from Barker's tragic drama has shown, the protagonist realises herself in the dissolution of her particular interests because her main concern is not (or no longer) an attack on the instrumentalising logic of the whole (the logic of political power). Her main concern is a realisation of her absolute and infinite singularity which, inevitably, is perceived as an attack on the whole. She no longer has particular interests to defend or statements to make, she only pursues her journey towards her self, which means a journey towards dissolution and death.

The tragic character's 'fascination with death' (Barker 2005, 71) presents a challenge to the imagination by juxtaposing the wrong world with, in Adornian terms, an 'as if' scenario of possibilities, a semblance of otherness. By challenging the coercive (instrumentalising) intelligibility of the world with the enigmatic 'incomprehensibility of the art-work', Barker's art of theatre - without passing judgment - exposes the spectator to pain, failure and forbidden desires, thus constituting an 'address' which returns the individual spectator to him or herself (see Düttmann 2003). Furthermore, tragedy's seductive performance of the 'ecstasy of vanishing meaning' (Barker 2005, 14) liberates the tragic character from the morality of the collective (which defends general interests). Barker's tragic theatre invites us to think within (by sinking into) and to think against (by reaching beyond) the mythic quality (or spell) of the social totality, this context of late-capitalist 'blinding' as Adorno has put it, which forces particularity into universal sameness. If the form of tragedy survives, then maybe it will be because it is a poetic form that allows us to look into the abyss of our self. For, as Adorno has noted in his discussion of Hölderlin, and which in my opinion resonates with the aims of performance philosophy: '[w]hat is poetized compels us to philosophize' (Krell 2010, 195).

\section{Works Cited}

Adorno, Theodor W. 1974. Minima Moralia: Reflections from Damaged Life. Translated by E.F.N. Jephcott. London: NLB.

1997. Aesthetic Theory. Translated by Robert Hullot-Kentor. London: Athlone.

1998. "Fantasia sopra Carmen." In Quasi Una Fantasia: Essays on Modern Music, translated by Rodney Livingstone, 53-64. London: Verso.

Barker, Howard. 1997. Arguments for a Theatre. $3^{\text {rd }}$ edition. Manchester: Manchester University Press.

2005. Death, the One and the Art of Theatre. London: Routledge.

2008. Plays Four (I Saw Myself et al). London: Oberon. 
Beistegui, Miguel de and Simon Sparks, eds. 2000. Philosophy and Tragedy. London: Routledge.

Düttmann, Alexander García. 2003. "Art's Address." In Adorno. The Possibility of the Impossible, edited by Nicoulaus Schafhausen, Vanessa Joan Müller, and Michael Hirsch, 85-91. Frankfurter: Kunstverein.

Jameson, Fredric. 1990. Late Marxism: Adorno, or, the Persistence of the Dialectic. London: Verso.

Krell, David Farrell. 2010. "Twelve Anacoluthic Theses on Adorno's 'Parataxis: On Hölderlin's Late Poetry'." In Language Without Soil: Adorno and Late Philosophical Modernity, edited by Gerhard Richter, 195-205. New York: Fordham University Press.

Lamb, Charles. 2005. The Theatre of Howard Barker. London: Routledge.

Nancy, Jean-Luc. 2002. Hegel: the restlessness of the negative. Minneapolis: University of Minnesota Press.

___ . 2014. "After Tragedy." In Encounters in Performance Philosophy, edited by Laura Cull and Alice Lagaay, 278259. Basingstoke UK: Palgrave Macmillan.

Paolucci, Anne and Henry, eds. 1976. Hegel on Tragedy. London: Harper and Row.

Steiner, George. 1961. The Death of Tragedy. London: Faber and Faber.

2008. "Tragedy,' Reconsidered." In Rethinking Tragedy, edited by Rita Felski, 29-44. Baltimore: John Hopkins University Press.

\section{Biography}

Karoline Gritzner is Lecturer in Drama and Theatre Studies at Aberystwyth University and a core convener of the Performance Philosophy network. Her research interests include contemporary British drama, modern European theatre, gender and sexuality, aesthetics and critical theory. She is the editor of Eroticism and Death in Theatre and Performance (2010), co-editor with Will Daddario of Adorno and Performance (2014), and author of Adorno and Modern Theatre (2015).

(c) 2015 Karoline Gritzner 